\title{
A DISCIPLINA DE HISTÓRIA DO DESIGN I
}

\section{Ana Paula Calvo \\ Arthur de Toledo Verga}

Universidade Mackenzie

No curso de design da Universidade Mackenzie, a disciplina de História do Design I compõe o primeiro de quatro módulos da disciplina História do Design, com uma carga horária semanal de duas horas aula. A ementa que caracteriza os quatro módulos é a seguinte :

"A evolução do design desde o seu surgimento com a Revolução Industrial, sua evolução na Modernidade, Pós- modernidade e contemporaneidade. Escolas, grupos, movimentos e estilos na história do design. História do design brasileiro e sua evolução. Percurso do design e as questões sociais, econômicas, culturais e tecnológicas."

Neste primeiro módulo o design é pensado de maneira ampla, sem um foco exclusivo, seja no design visual seja no projeto de produto. 0 campo do design é analisado identificando-se semelhanças e diferenças, continuidades e mudanças entre os momentos históricos estudados e as diferentes manifestações de design atuais. Por constituir o módulo inicial, à História do Design I cabe o papel de sensibilização e questionamento em relação à idéia de história e às concepções de design que orientam as "histórias do design" de autores e tendências diversas. À disciplina também compete a reflexão sobre o campo do designem perspectiva histórica, e esta acontece centrada na análise do binômio projeto/execução e da idéia de reprodutibilidade em diferentes momentos históricos, analisando-se o contexto, as condições de produção, as características formais e estilísticas e as concepções filosóficas e estéticas de diferentes tendências, movimentos e estilos.

Em parceria com outras disciplinas do mesmo semestre, História do Design I também trabalha a conscientização acerca da natureza interdisciplinar do campo do design, de seu papel social, do impacto de qualquer projeto sobre o meio em que está inserido e da necessidade e valor da atuação crítica e consciente do designer.

O conteúdo programático que alimenta os diferentes objetivos da disciplina constitui-se, inicialmente, da análise das concepções de design de Phillip Meggs, Adrian Forty e Rafael Cardoso. Em 
conjunto com essa análise aborda-se a idéia de autonomia da arte e a divisão entre artes maiores e menores. A reflexão em torno do binômio projeto/execução e da idéia de reprodutibilidade acontece em função de alguns temas e momentos históricos:

- o livro xilográfico/ tipográfico e o surgimento da tipografia na Europa dos séculos XII, XII e XIV;

- a produção de cerâmica na Inglaterra dos século XVIII, com foco no trabalho de Josiah Wedgwood;

- o design vitoriano, a mecanização e a disseminação das exposições universais na Inglaterra do século XIX;

- o design gráfico e a revolução industrial na passagem dos séculos XIX e XX em diferentes lugares do mundo;

- o reformismo social e as idéias do movimento Arts and Crafts na passagem dos séculos XIX e $\mathrm{XX}$;

- o design no Brasil e na América Latina e as aproximações e distanciamentos em relação ao design na Europa;

- a idéia de estilo internacionalizada no século XIX: o Art Nouveau.

A metodologia envolve aulas expositivas, análise e debate de textos e filmes em sala de aula, visita a exposições de arte e design.

A avaliação é constituída por análises individuais ou em dupla de projetos e textos em sala de aula, assim como a participação em grupo no PI (Projeto Integrado) do semestre, que objetiva a elaboração de um projeto interdisciplinar em programação visual ou projeto do produto e que reúne as disciplinas de Metodologia do Projeto, Materiais e Processos Gráficos, Tipografia, Teoria do Design, História do Design, Computação Gráfica e Desenho.

A Bibliografia procura contemplar títulos que abordem tanto o design visual como o projeto de produto. Para a Bibliografia Básica foram selecionados títulos mais panorâmicos e para a Bibliografia Complementar títulos que aprofundam determinados temas e que abrem algumas janelas na reflexão sobre o campo do design.

\section{BIBLIOGRAFIA BÁSICA:}

1. CARDOSO, Rafael. 0 design brasileiro antes do design: aspectos da história gráfica, 1870-1960. São Paulo: Cosac e Naify, 2005.

2. . Uma introdução à história do design. São Paulo: Edgard Blücher, 2000.

3. FORTY, Adrian. Objetos de Desejo. São Paulo: Cosac e Naify, 2008.

4. HESKETT, John. Desenho industrial. Rio de Janeiro: José Olympio, 1997. 
5. MEGGS, Philip B. História do Design Gráfico. São Paulo: Cosac e Naif, 2009.

\section{BIBLIOGRAFIA COMPLEMENTAR:}

1. BURDEK. Bernhard. História, Teoria e Prática do Design de Produtos. São Paulo : Edgard Blucher, 2006.

2. CARDOSO, Rafael, LUSTOSA, Isabel, ANDRADE, Joaquim M. F., GARCIA, Lúcia. Impresso no Brasil: destaques da história gráfica no acervo da Biblioteca Nacional. Rio de Janeiro: Verso Brasil, 2009

3. HOLLIS, Richard. Design Gráfico: uma história concisa. São Paulo: Martins Fontes, 2000.

4. MUNARI, Bruno. Artista e designer.SP: Almedina, 2004.

5. RAMOS,E.,MELO,C.H. Linha do tempo do design gráfico no Brasil. SP:Cosac e Naif,2012. 